\title{
Elementary Structures in the Nepal Himalaya: Reciprocity and the Politics of Hierarchy in Ghale-Tamang Marriage
}

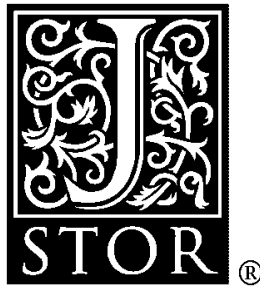

\author{
Thomas E. Fricke \\ Ethnology, Vol. 29, No. 2. (Apr., 1990), pp. 135-158.
}

Stable URL:

http://links.jstor.org/sici?sici=0014-1828\%28199004\%2929\%3A2\%3C135\%3AESITNH\%3E2.0.CO\%3B2-3

Ethnology is currently published by University of Pittsburgh- Of the Commonwealth System of Higher Education.

Your use of the JSTOR archive indicates your acceptance of JSTOR's Terms and Conditions of Use, available at http://www.jstor.org/about/terms.html. JSTOR's Terms and Conditions of Use provides, in part, that unless you have obtained prior permission, you may not download an entire issue of a journal or multiple copies of articles, and you may use content in the JSTOR archive only for your personal, non-commercial use.

Please contact the publisher regarding any further use of this work. Publisher contact information may be obtained at http://www.jstor.org/journals/upitt.html.

Each copy of any part of a JSTOR transmission must contain the same copyright notice that appears on the screen or printed page of such transmission.

The JSTOR Archive is a trusted digital repository providing for long-term preservation and access to leading academic journals and scholarly literature from around the world. The Archive is supported by libraries, scholarly societies, publishers, and foundations. It is an initiative of JSTOR, a not-for-profit organization with a mission to help the scholarly community take advantage of advances in technology. For more information regarding JSTOR, please contact support@jstor.org. 


\section{ELEMENTARY STRUCTURES IN THE NEPAL HIMALAYA: RECIPROCITY AND THE POLITICS OF HIERARCHY IN GHALE-TAMANG MARRIAGE}

Thomas E. Fricke

University of Michigan

The relationships organized by marriage and kinship in small scale societies have long been a mainstay of anthropological approaches to society. These approaches have, however, varied in contentious ways through the years. Some have stressed adherence to positive rules of marriage and behavior embedded in kinship terminologies (Lévi-Strauss 1969 [1949]); others have stressed social organization as an outcome of statistical patterns of behavior (Murdock 1949). Still others have discussed social organization in terms of decision-making models, themselves structured by an embedded hierarchy of rules available to the conscious repertoire of social actors (Keesing 1967). More recent and promising analyses have attempted to join the improvisations of human agency with accounts that recognize the role of structured historical relationships and their strategic recreation (Bourdieu 1977). These are largely subsumed under the heading of practice approaches (Ortner 1984, 1989:11-18) and themselves encompass applications to various sets of data from historical (Bourdieu 1976) and secondary ethnographic sources (Collier 1988) to actual analyses of process among contemporary groups (Bradburd 1984).

Among the advantages of practice approaches is an explicit concern with individual strategic behavior conducted within particular contexts of meaning and prestige rather than in response to an integrated, highly structured set of rules (Bourdieu 1976:119-120). This stress on defining particular local contexts does not exclude economic considerations from the understanding of practice although they are not given a priori analytic prominence. Moreover, where other approaches have stressed logical coherence, either in parallels between behavior and terminology or in normative systems, the practice perspective allows for the simultaneous existence of apparently contradictory motivations. Indeed, these points of tension provide actors with the alternatives that give flexibility to social systems. Leach recognized the importance of these inconsistencies in his work on the Kachin, suggesting that the "overall process of structural change comes about through the manipulation of these alternatives as a means of social advancement" (1977:8).

Recent work demonstrates the pivotal position of marriage in recreating and extending political and domestic statuses in classless societies. Much of this work, however, seems to imply that any particular society will be defined by highly integrated ideal models which define the differences along which inequalities are structured. Jane Collier's (1988) three models of social inequality defined by marriage, for example, take social inequality as a necessary condition in all societies, but appear to assume single discourses of social interaction within any particular setting. Even Leach's recognition of 
multiple Kachin $(1961,1977)$ systems assumes a great deal of coherence in any particular village although one system may transform into another through time.

Few studies have looked at the dynamic of strategic variation within a single village setting. In this paper I examine such variation in marriage within a single Himalayan village in which conflicting models of equality and social difference coexist. I begin by establishing the conflicting themes of equality and hierarchy that characterize Timling people's images of themselves. These themes are ratified in the meanings attached to exchange in village social life and are separately legitimated with reference to particular clan histories. They are tied to the categories of social difference and to the structure of production that organize life in Timling. Marriage represents a key institution for reproducing these relationships and I conclude by demonstrating how the strategic manipulation of marriages within the context of history and structures of meaning serves to create and renew relations of equality and hierarchy within Timling's dual system of prestige (Collier 1988:196; Bourdieu 1976:141). Elements of this system include the cultural models motivating behavior, historical relations between groups, axes of socially recognized difference, and the concrete behaviors of marriage strategies themselves.

\section{TIMLING: TWO MODELS JOINED}

Timling is a nucleated settlement of Tibeto-Burmese language speaking agro-pastoralists lying on a narrow shelf of land about 7,500 ft. above sea level. Its organization and economy align it with the organization of other groups throughout the Nepal Himalaya, from those with more direct Tibetan cultural orientations (Levine 1988; Ortner 1978, 1989) to the range of middle hill populations comprising the bulk of Nepal's ethnic population (Messerschmidt 1976; Molnar 1978; Hitchcock 1980; Holmberg 1989; Zurick 1989). Most of these villages have been settled in successive waves of immigration by pioneer ancestors whose descendants are organized into exogamous patrilineal clans. Many, but not all, are characterized by locally idiosyncratic systems of ranking that of ten place the descendants of the earliest arrivals in a superior relationship to those of later arrivals. Timling itself is inhabited by two groups who regard themselves as ethnically distinct in spite of two centuries of intermarriage, the Ghale (or Ghle in the western Tamang dialect) and the Tamang. When the people of Timling compare themselves to other Tamang and Ghale villages along the Ankhu River valley and beyond, they stress the essential equality of their social relations, their lack of social differentiation. "Here we all have one stomach (Tm. ${ }^{2}$ pho $g i$ )" they say. Or, "Here we are of one mind (Tm. sem gi)." Both phrases have many levels of meaning, but the core metaphor of "one stomach" implies in addition to eating out of a single pot that what they have is shared, that there are no differences to inhibit relationships among them. In the same way, when asked why they never use the honorific terms of address available to them in their Tamang language (as, for example, Tm. teng for "you"), they laugh and call them "Jharlang talk" in reference to a village about a day's walk to the south. Here in Timling, everybody uses $e e$, the familiar Tamang term of address. 
The ideology of marriage exchange parallels this emphasis on sharing and reciprocity among people known to each other. When asked about a proper marriage partner for men, some will answer that it is "either a mother's brother's daughter or a father's sister's daughter." More often, one hears preference phrased in terms of the father's sister's daughter. Their replies are consistent with the ideology of continuing restricted exchanges embodied in bilateral cross-cousin marriage and reported throughout the Tamang area (Fürer-Haimendorf 1956; Höfer 1969; March 1984; Holmberg 1989; Tof fin 1986).

These markers of Timling's organization and view of itself relative to the outside indicate an egalitarian society organized on the basis of reciprocity. Yet even as all people express these egalitarian ideals, a countervailing ideology of social difference and hierarchy introduces a paradox. On the one hand, both Ghale and Tamang accept the precedence of FZD marriage and the serially balanced reciprocities embodied by bilateral cross-cousin marriage and restricted exchange. On the other, both groups accede to a ranked construction of social difference related to Tibetan divisions of society widely documented in the Nepal Himalaya (Allen 1978; Levine 1988:63-67; Pignéde 1962; Messerschmidt 1976:5-6). These ranks are inherited, yet define the very groups who enter into reciprocal marriage relations in Timling.

The questions arising from this contradiction are central to our theoretical understanding of social inequality and its reproduction in kin-based societies. Timling people explicitly view marriage as a key event for creating and renewing relationships between patrilineally defined groups. They also view marriage as an important watershed in the relationships between individuals within the same domestic groups, especially to the extent to which it presages household and property fission.

\section{Prestige and Reciprocity in Timling}

Sharing food is an act of social belonging open to anyone in the village. Walk into even the poorest household and the first offering after being seated near the hearth will be from the cooking pot of boiled potatoes (Tm. teme) or porridge (Tm. ken), depending on what food is in season. If there is beer, it is immediately offered (cf. March 1987). The offering and acceptance of vegetable food and beer, the staples of local life, connotes a common identity among the sharers. They are of one stomach.

Giving carries no threat of diminishment. Even more, giving food is itself a requisite of abundance, a view that finds ratification in both mythic themes and in practice. Thus, Holmberg (1989:53) recounts a myth in which the sharing of a tiny bird snared in hunting results in the redoubling of its meat to an extent requiring two people to carry it on a pole between them. Variants of this myth are widespread throughout the Tamang area. Similarly, when a group of households has purchased an animal for slaughter any person who comes later and requests to be included in the subscription is automatically given a share of meat. There is always enough. ${ }^{3}$

Underscoring the centrality of these core social values are the sanctions levied against those who violate the ethic of sharing. The failure to give without obvious calculation from the produce of one's hearth is the source of accusations of greed (Np. lobh). Such accusations are directed against any household and its members in which whatever food or drink present is not 
shared with a visitor. They are also directed against one's own family members who fail to give labor or service where they are expected to do so. Thus one man in Timling began to develop his reputation for greed when he failed to turn over his earnings from roadwork outside of the village to his father after his return. His nefarious reputation grew when he began to acquire other people's land as they took loans from him and were unable to pay him back at agreed upon times. The consequences of his acquisitiveness reflect the more general consequences of greed in Timling. His wife is widely held to be a witch, beings who are thought in Timling to consume the souls of others and from whom food should not be accepted since it is likely to cause the withering of one's body. People avoid his household and refuse to accept food there. While no one fails to offer members of his family food should they enter another household, the powerful daily signifier of community, the exchange of food in two directions, has been severed for this household.

This sharing of one's produce around one's own hearth is a precondition for sociality in Timling. There is no choice and no extraordinary prestige in the sharing. Although giving may at any one moment imply a mild superiority in the oscillation of reciprocity, the act of accepting food at a hearth implies the right of the giver to become a recipient at a later time and there is no permanent advantage or sense of competition in the exchange. Since every family in Timling owns at least some arable land (Fricke 1986:158-163), every family has access to the exchange values derived from sharing food.

Although giving is basic and implies equality where reciprocity is in kind, it may also imply hierarchical relationships when such return cannot be realized. The manner in which giving is converted into prestige is prefigured in another form of transfer that is, once again, open to and expected of all married males regardless of their village-wide standing. Thus, a father is expected to provide "seed" (Np. biu) to all of his sons when they claim their inheritance. In this case "seed" refers to all that is essential to the fortunes of the new domestic group--land, seed grain, starter herds, and the essential tools of production. While this transfer, as with the sharing that occurs around the hearth, is a requirement of any father, it results in the creation of a new domestic group and hearth and embodies relationships parallel to those entered into by people who acquire extraordinary prestige.

This same marker of status within the domestic cycle leading to fission is parallelled at the level of village politics where status is partially acquired by the ability to give beyond the circle around one's hearth. Village reference to past political leaders make it clear that the marker of high status was the ability to give widely. Margyelbo, a Ghale headman born around 1840, is remembered as a powerful man who commanded the labor of large numbers of affines who worked his fields and hauled grain to Tibet in exchange for salt. $\mathrm{He}$ is also remembered as a man who opened his granaries to provide seed to all Timling households in times of shortfall. Similarly, the most powerful Ghale patriline in the village today provides the meat of a cow to all of its affines at the close of the fall harvest every year. The mark of this affinally based status is again to give more widely than the hearth.

One can view the relationships created by any of these transactions in terms of the idiom of respect and debt (Collier 1988:77). Simple sharing around the hearth assumes a non-calculative, but no less real, obligation of 
return when the giver is him or herself a visitor to the recipient's hearth. All of the other relationships--between fathers and sons, affines, and Margyelbo and the recipient households--assume reciprocities in the form of labor and services rather than in kind. Within their natal homes, sons are expected to give not only their labor but the product of their labor performed elsewhere to their fathers. After household fission, they continue to provide labor and services. Wife-takers have a similar responsibility to provide labor and services to their affines. Margyelbo's recipients of grain provided labor, as well as political allegiance, to his household.

A final order of giving, however, creates a more enduring prestige that redounds to the status of a giver's descendants across the generations and connotes historical validation of contemporary status claims. Here prestige claims interact with descent ideology in Timling where members of the same patri-clan are said to share "one bone" (Tm. nakhrut gi). Margyelbo's lineal descendants unambiguously invoke his name and their connection through bone in any conversation that touches on status. Male clan ties are affirmed in life cycle rituals that separate them from women. In events preparatory to a chewar ( $\mathrm{Tm}$.), a first hair-cutting ceremony that marks a boy's initiation into personhood and recognized clan membership, a patriline elder recounts the boy's genealogy as juniper boughs ( $\mathrm{Tm}$. shukpa) burn in an offering to the ancestors. Claims to status wider than that growing out of individual relationships of the living are recounted.

As if to concretize these claims, the power and prestige of high status deceased are memorialized in final acts of giving by building religious cairns (Tm. mane) in their name. ${ }^{4}$ These cairns contain relics of the deceased as well as parchments containing their "name" (usually the Tibetan name for the animal year (Tm. lho) of their birth). Other enduring gifts include sections of village trail, riprapped and topped with fresh stone, and trailside resting places built in the name of the powerful deceased by their families. All of these are interpreted as continual acts of giving beyond the hearth for the benefit of the entire village and none can be easily reciprocated.

Political leadership follows this same continuum from the hearth. Within the household senior males take precedence. Each adult male household head has access to the labor and commands the respect of household members. At any meal, a plate is set aside for the god of the hearth (Tm. kulgi lha)--also called "grandfather" (Tm. meme)--by the senior male in the household. The senior male also takes the first bite of food as a way of protecting his family against the envy of this ancestral hearth god. In the same way, the senior male within any patriline is recognized as the headman of that group because he naturally commands the respect of his juniors for whom he has provided seed. The status of clan headman is based on the extent of one's patriline; to be the senior male in a large patriline means that one commands the loyalty of a larger number of households. It also means that one has given more by providing the seed that established those households. At this level, leadership exists in terms of debt and respect. Similarly, the widest political leadership of the village was available in this system to the head of the patriline which had provided for all households regardless of relationship as had Margyelbo in the past. Thus, village-wide political leadership may be thought of as an extension of the more domestic orders of prestige and status. 
In this way, two orders of giving and exchange are embedded in the expectations of reciprocity that run from the domestic realm through village-wide relations. One involves simple reciprocities of exchange in kind and consequent ratification of the ideology of oneness. The other recognizes the need to reciprocate but allows for a return in the form of labor and services in return for concrete elements of production such as land and seed.

\section{Social Difference in Timling}

While these behavioral signals of common identity and hierarchy are subject to manipulation, they are carried out within the context of social categories that are themselves ranked. These categories of social difference along which status can vary include those which are relatively permanent to the more transitory and relational. Clan and patriline status is fixed in terms of theories of descent from a common male ancestor whose descendants share of one bone. Gender differences are also permanent. More temporal categories include the statuses that people move into and through as an outcome of simply living their lives and aging in society. Some of these categories are relative statuses and exist as long as the two people in a relationship are alive together, as in being a son or a daughter to another person; others are quasi-permanent categories entered into at specific transitions in the life course, as in entering the state of marriage. There is also the differential status between older and younger siblings and first and later wives. Given the ideology of descent, these also have an impact on their descendants' status. Both permanent and relational forms of social difference come into play in the discussion of marriage in Timling.

Hierarchy and mythic validation. Two encompassing systems of social differentiation exist together in Timling. One of these is patterned after the four-fold division of Tibetan society into endogamous royal, ministerial, priestly, and commoner groups (Allen 1978; Aziz 1978:51-57). The difference in Timling is that this natural social order is associated with exogamous clans. ${ }^{5}$ The more fundamental division in Timling, however, is that between the royal clan, the Ghale, and the four Tamang clans. Timling people describe their differences as being on the same order as the difference between castes in wider South Asian society, at least in the sense of there being a hierarchy of "kinds" (Np. jat). Both groups agree that the Ghale are "higher" and non-Tamang. This status is reflected in Timling's naming system in which Ghale append -gyelbo and -gyelmo to their names, Tibetan-derived words for king and queen. The four Tamang clans are regarded as of closer status among themselves and identical to clans found throughout villages of the western Tamang region (Höfer 1969; Toffin 1986).

As with other Tibeto-Burmese populations (Levine 1988:26-34; Messerschmidt 1976; Pignéde 1962; Clarke 1980), the legitimacy of status claims within the village is validated by stories of arrival. In Timling these accounts are oral and, as elsewhere, variants exist for every clan. All Timling residents agree that the Tamang clans settled the area first, their ancestors arriving from the northeast.

Ghale, on the other hand, say that their ancestors arrived from the northwest, variously representing themselves as coming from more Tibetanized areas of Manang or as having an association with the Shah kings who 
eventually unified the Hindu Nepal state (Stiller 1973). Widely repeated versions of their coming not only stress their ascendancy but validate an inversion of the usual Tibeto-Burmese pattern in which late comers are accorded lower rank.

Timling people say that prior to the arrival of the Ghale, the Tamang had their own king--Bongzo Raja--who began to act in an unkingly manner by demanding that special foods be provided to him daily and by increasing his labor demands on the people of Timling. In retaliation, the Tamang went northwest where a shaman told them they would find their new king. $\mathrm{He}$ would be recognized as the one child in a crowd of children from all castes who protected himself from becoming dirty by sitting on a wool blanket. Such a child was found and the Tamang carried him to Timling on their backs, naming him Khuruwa which Timling people say is Tibetan for "one who is carried." Bongzo Raja and his supporters were defeated and fled. Today, all Timling Ghale ${ }^{6}$ claim Khuruwa as their apical ancestor and place his arrival as roughly ten generations ago, precisely the period when the Shah kings were expanding from their base in Gorkha to conquer the hill villages toward Kathmandu (Stiller 1973).

These Ghale ancestors were presented with a problem in that they represented only one exogamous clan, the Geldang, out of eleven Ghale clans said to have formed an endogamous marriage community. The problem confronting the original Ghale in Timling was how to maintain ascendancy when reciprocal marriage exchange with the same groups implies social equality. In another story of arrival the Ghale suggest that in the original exchanges "the Tamang took our daughters first."

Thus, the Ghale claim high rank in local society because: (1) they are pure by virtue of descent from Khuruwa who separated himself from the dirt with a blanket; (2) their apical ancestor was brought to Timling by Tamang, thus establishing a primordial debt with no possibility of reciprocity in kind; (3) their daughters were taken first as wives and Ghale thus stand as ancestray wife-givers. While these histories suggest the validation of clan statuses in Timling, at least insofar as distinguishing between Ghale and Tamang, they leave questions about the maintenance and reproduction of these relationships unanswered. The processes involved in this maintenance will be taken up in the later discussion of marriage.

Gender. Since marriage unites patrilineal groups through the transfer of women, local ideas of gender are an important element of the system of relationships (Collier 1988). Although the Tamang and Tibeto-Burmese peoples more generally have elsewhere been noted for the relatively egalitarian standing of males and females (Acharya and Bennett 1981), gender nevertheless represents an important divide. March (1984) has analyzed the different symbolic associations with maleness and femaleness in western Tamang society. She demonstrates the contrasting themes of male association with solidity and enduring structures embodied in clan continuity and the female association with binding these clans into a larger society through marriage exchange.

These differences are tied, as well, to the ideology of descent and the transfer of common substance (cf. Levine 1981). Men contribute bone to their descendants and form a link that endures across generations of uncounted number. Women contribute flesh (Tm. shya), an ephemeral 
substance. While no person of the same bone can ever marry, people are of the same flesh for only two generations; descent through a common mother, or of "one milk" (Tm. nyeh gi) sisters (sisters who have nursed at the same breast) precludes marriage for only one generation. Thus, the children of actual sisters are prohibited marriage regardless of their fathers' clans. The next generation of children may, however, marry if their fathers' clans are appropriate.

While women retain their clan identities after marriage, they are not key actors in the important rituals of clan solidarity and identity (for example, the chewar preliminaries in which genealogies are recounted; or the chheju, village fairs, sponsored by patriline members in a common neighborhood). The ideological solidarity of men is buttressed, too, in daily life. Men inherit most of the land essential for agriculture and the process of division in the partible inheritance system insures that the shape of one's patriline is mapped in the ownership of fields surrounding one's own. Brothers will always have adjacent plots, surrounded by those of patrilineal cousins. Moreover, the knowledge of specific patriline connections is essential for cases in which a domestic group fails to reproduce itself through its own children. The land belonging to the failed domestic group is reabsorbed into the lands of the closest agnates. While women have a truncated form of land inheritance in which garden plots within the village area may be passed from their mothers, it is not a universal practice (only 32 of 100 women reporting any kind of inheritance also reported receiving land). Moreover, the ideology of descent means that their patriline links cannot be mapped in land in the same way as that of men.

Women are largely precluded from achieving access to prestige except to the extent that they are tied to a particular domestic group associated with their husbands. Even though they are primary actors in daily acts of reciprocity and co-operative work groups, the land from which comes most of the produce necessary for establishing prestige in the village is owned by men. Moreover, women can never command the labor of men in an unbalanced way and the labor they share with other women is always reciprocal.

Generation. Age, and Affines. The last important category of social difference includes those types of differentiation that, while they may rank any two individuals permanently with respect to each other, do not define one's relationships in village-wide terms. Thus one may have older sibs as well as be an older sib to others. One may be in a younger generation relative to one's father but have children of one's own. One may take a daughter from another clan as well as give a daughter. Throughout Timling society senior generation membership connotes status and demands respect. Relative age within a generation similarly relates to status. Older brothers rank higher than younger. Wife-givers rank higher than wife-takers. All of these statuses define obligations in terms of respect and rights to labor, while the relationships entered into through the exchange of women go beyond domestic statuses and may be manipulated for political ends. 
The meanings assigned by Timling people to exchange and forms of giving, together with their structured categories of social difference make it clear that the environment of production is an important component of their relationships, too. Prestige in Timling is tied to the ability to give to others, an extension of the basic requirements of sociality incumbent on all people. The social organization of production is thus tied to access to prestige. Any single domestic group's fields are dispersed throughout the altitudes that constitute the agricultural zone of production (Fricke 1986). It is impossible for any individual to combine the elements of subsistence on his own since the work of tending fields near the village is at least a day's remove from the high pastures where sheep and goats are herded in the summer months. Even if a family were to forego pastoral production, agricultural fields belonging to a single domestic group are often a day's walk or more apart. Co-operation is essential for the production of goods that allow Tamang and Ghale to share food even at a minimally acceptable level.

Since prestige and status, and the leadership that goes with it, exist along a continuum from simple domestic statuses between family members to increasingly wider groups of patriline and clan headmanship to village headmanship, any person has a variety of prestige options available to him. All forms, however, require access to labor to increase production. At a minimum, every household head has the labor within his household at his disposal and the potential for giving is tied to the abundance of crops produced within a domestic group. Until quite recently, Timling's environment included huge tracts of unclaimed arable land resources in the forests above the village. Any domestic group could expand its holding into this land through the simple expedient of clearing the trees and planting crops. Opened land belonged to the family that cleared it. Thus the ability to give was tied directly to the size of the domestic group. More expansive forms of prestige require more labor than that available within a single domestic group, however, and the means of obtaining that labor is through the obligations of wife-takers to their affines. For affines providing labor, the advantages of their connections to wealthy patrilines are realized partly in obtaining usufruct rights over excess lands for the duration of their marriage. Several sons-in-law to one wealthy patriline, for example, receive such land in exchange for their labor. In a similar way, an inter-village alliance organized by marriage gave seasonal pasture rights to affines in both villages.

Credit for giving is largely available only to male householders and those associated with them. This credit is tied to production from agricultural land, again available only to married men. Labor can only be unequivocally demanded from ones own children and from affines unless one is in the position to create indebtedness more widely. Since the path to this ability is itself contingent on a firmly established domestic base in which increasing amounts of labor can be mobilized in the process of domestic developmental cycles (Fricke 1986), the disposition of marriage and access to women are crucial elements of prestige. 


\section{MARRIAGE AND THE ETHOS OF RECIPROCITY}

The Ghale say that as a result of drinking the Timling water they have given up their Ghale language. Today, one hears only a few Ghale words of address around the hearth in their neighborhoods and everybody in Timling speaks the western Tamang dialect. Just as the Ghale assumed the Tamang language and made it their own, they have also assumed Tamang ideologies of marriage practice.

Marriages are expected to involve individuals and their closest kin in relationships of specific obligation throughout the life of the union. Some of these relationships are discussed in reports from other western Tamang villages (Höfer 1969; March 1979, 1984; Holmberg 1989). The key obligations established or ratified by any single Timling marriage involve a central wife-taker, his wife's father (Tm. ashyang), and his wife's brother (Tm. shyangbo). This is an obligation of debt entered into by virtue of having taken a woman from their household and, by extension, from their patriline. To the ashyang and shyangbo, the wife-taker is mha (Tm.); mha are expected to provide labor and services throughout the seasonal round as well as at specified ritual occasions, most dramatically at the funerals of members of their ashyang-shyangbo households. Of course, as Holmberg (1989:66) notes these primary units of relationship do not exist in isolation. Nearly every mha will in turn have mha beholden to him if he has a sister or a daughter. The general picture is one of wife-takers ( $m h a)$ providing services to their wive-givers (ashyang-shyangbo).

Such structured obligations are consistent with kinship-ordered hierarchies as well as egalitarian relationships (Lévi-Strauss 1969; Leach 1961). Within the Tamang system of preferred bilateral cross-cousin marriage, ideally realized, they create at minimum an oscillating equilibrium across generations in which the overall relationship between patrilines is balanced. The people of Timling phrase their preferences quite explicitly in terms of a son having first claim to his father's sister's daughter, as is true in the entirely Tamang village of Tamdungsa (Holmberg 1989:58-59). The logic of repeated marriages of this type would place a married man's mha and ashyang-shyangbo within the same family. Indeed, his classificatory wife's brother, to whom he owes service, would be the same person as his classificatory sister's husband, who owes him service, resulting in a balanced reciprocity in the same generation; the prestige value of acquired labor therefore redounds only to the senior generation, to the ashyang, since ego and his mha-shyangbo break even in the exchange of classificatory sisters.

Reality is not so neat as this logical system, of course. While all Timling Ghale and Tamang accept the obligations constructed by marriage (cf. Holmberg 1989:59), people of ten go outside of even classificatory FZD to obtain a wife. More important than the stated "correctness" of FZD marriage in Timling are the compelling negative sanctions levied against those who enter into forbidden marriages. In the upper Ankhu Khola area, at least, marriage to a forbidden category of relative, one with the same bone, resulted in the past in enslavement.

While the negative sanctions are ironclad, the range of possibilities for marriage, all acceptable in Timling and among western Tamang, include: (1) those in which husband's and wives had no recognized traceable kin link 
before marriage; (2) those in which a wife was related only as a real of classificatory MBD before marriage; (3) those in which a wife was related only as a real or classificatory FZD before marriage; and (4) those in which a man's wife was both a classificatory or real MBD and FZD before marriage.

All of these marriage forms have different implications for enduring patterns of obligation across generations and are statements of the relationship between patrilines. All are acceptable since, while their is an "officialized" preference (Bourdieu 1976) for marriage exchange of the repeated FZD kind, the active constraints to marriage between any two people are the rules of exogamy. Understanding Timling marriages as the key to reproducing inequalities demands a look at the continuing relationships each form engenders in terms of its origin in prior social relationships and contexts of meaning. A look at the possibilities for marriage and their implications for the position of mha and ashyang-shyangbo will make some of these clear. (See Figure 1 for diagrams of the relationships communicated by marriage with socially recognized relatives.)

Figure 1: Possible Structures of Marriage with Classificatory Relatives in Timling

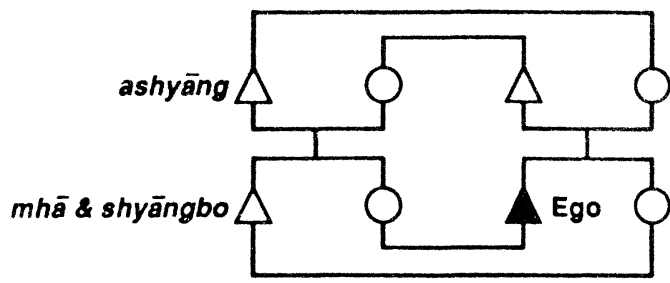

Continuing MBD-FZD Exchange Marriage
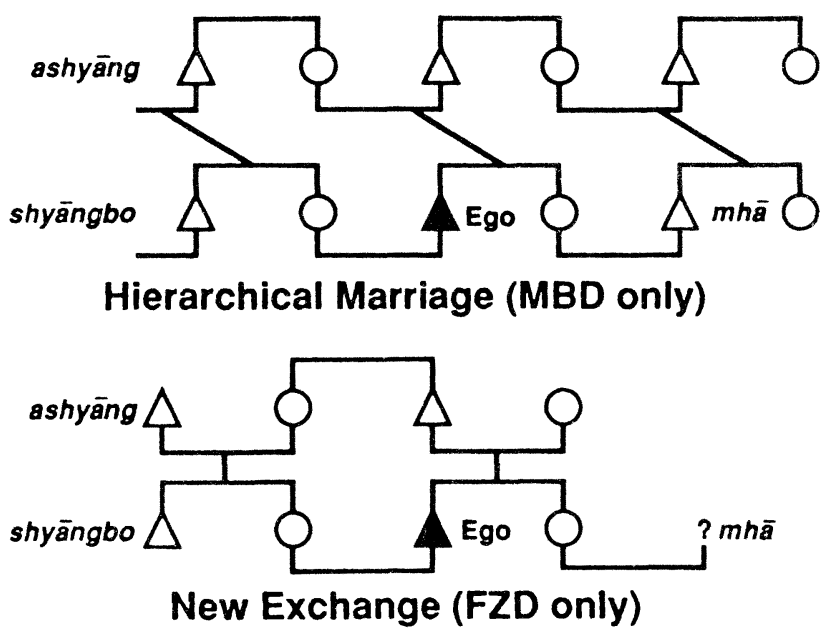
Any single MBD marriage implies a consistent one-way flow of obligations replicated for at least two generations. Women move in one direction and the labor and service obligations move in the other. Reciprocity structured by the exchange of women and these obligations is denied. We have already examined the implications of repeated FZD-MBD marriages. Marriages in which prior relation is recognized only as FZD have implications which are similar. Such a marriage suggests a recognition of the essential equality of these families and reciprocity is fulfilled in the rhetorically appropriate way across generations. These marriages are the result of a desire to create the same relationships of reciprocity engendered by MBD-FZD marriages although the full reciprocity remains unrealized until the marriage of ego's sister or until the following generation.

Marriages contracted without recognized kin links in prior generations (not diagrammed), on the other hand, suggest the establishment of completely new obligations, although they are expected to be taken no less seriously than affinal obligations renewed in other forms of marriage. While specific individuals automatically enter into relationships of obligation, no statement concerning enduring statuses that transcend single domestic groups is made by these marriages. The playing out of enduring relationships and status claims at the lineage level in these marriages are unknown since they may result in marriages of any other type in the next generation; links may be continued reciprocally or hierarchically or even discontinued altogether.

\section{THE PRACTICE OF MARRIAGE IN TIMLING}

The types of marriage into which Timling people may enter imply three orders of reciprocity and hierarchy: (1) new links between families without prior recognized relationships that by themselves communicate no statements about enduring relationships between patrilines; (2) MBD marriages which imply enduring hierarchical relations between patrilines; (3) reciprocal links continued by FZD and FZD-MBD marriages. These last marriages approach the rhetorically "orthodox" ideal of exchange in Timling and wider Tamang society. Given our understanding of marriages as concrete markers of status claims, we might expect the particular form of marriage enacted to relate to characteristics of spouses and their families.

Within the context and logic of Timling marriages described above we might expect relationships enacted by marriage to reflect strategies that differ with respect to membership in Ghale and Tamang patrilines. Ghale clearly have a greater historical "interest" in maintaining status claims; they are also able to mobilize their histories in validating continued hierarchical marriages with local Tamang. At the same time, while it may be easy to give daughters in marriage within Timling, the Ghale need also to bring other people's daughters in as wives. One strategy for avoiding the daily call of obligation established in taking wives is to find them outside of the village. Thus the proximity of affines should also be an important element of marriage strategy. Similarly, if the disadvantage of entering into hierarchical relations through marriage is assuaged by potential access to land, then the relative land holdings of families at the time of marriage will be an important element of marriage strategy. 
Two other characteristics of the marriage process require examination. If the goal of adhering to exchange principles is a dominant part of Timling strategies, then older daughters might be more likely to enter into these reciprocal forms of marriage. The lack of correspondence between birth order and marriage form, on the other hand, might be taken as further support for the argument that marriages are not organized in simple response to positive rules of exchange. Finally, we need to consider the multiple avenues of marriage decision-making possible in Timling. In Timling, marriages may include a full complement of exchanges and be arranged by senior members of domestic groups ( Tm. milsing bhya). They may also be more informal "elopement" marriages (Tm. chorsing bhya) contracted between spouses themselves, of ten with the tacit approval of senior kin. There should be a relationship between the relative involvement of senior kin and daughters in the tendency to enter into marriages that imply continuing relationships between patrilines. These dimensions of marriage are known for women in the village and their relationships will be explored following a look at two particular patriline histories.

\section{Marriage in Two Lineages}

Each Timling clan includes several patrilines which embody different histories of status claims organized by marriage. A comparison of the relationships created and maintained by marriage in particular patrilines illustrates the connections between past statuses and the manipulation of new relationships.

Figures 2 and 3 present the known structure of marriages for two lineages, one making prestige claims as the descendants of Margyelbo, the other a Tamang lineage making no particular claims to high status. Margyelbo, remembered as a powerful figure by all Tamang and Ghale in Timling, had two Tamang wives from the village. Present day members of his group can point to several mane built in the name of lineage members. The process of achieving and maintaining prestige are reflected in the disposition of marriages beginning with his own children from his senior wife and continuing through four generations of his descendants. (Comparable generations are indicated in the two figures by roman numerals.)

Margyelbo's eldest son was the first Timling man to be given a wife in an arranged marriage with a powerful family in Kimtang, a village about three days walk to the south. This constituted the first link in an enduring alliance lasting about 100 years. Both of the younger, and hence lowerranking, brothers were given Tamang wives from Timling. His first two daughters were given locally and the third daughter to a Tamang man in the neighboring village of Sertung, about an hour's walk from Timling.

By looking only at descendants through Margyelbo's oldest son and grandson, we see how a high status patriline can control the apparent contradiction of needing to give wives locally to establish debts while avoiding the implications of taking wives locally by contracting marriages that create obligations outside of the local arena. Every MBD marriage entered into by a Ghale male in this lineage involves women from Kimtang, a village distant enough that the implied lower status of wife-takers need not have translated into an actual claim on labor. Moreover, such marriages become 
indicators of high status in the local context since they represent a regional alliance with powerful families closer to influence with the Nepal state. At the same time, every marriage that brings a woman from outside of the village signifies one less possible claimant to labor services and the status that goes with it within the village, that is, one less active ashyang-shyangbo in the village area.

Ghale women from this lineage, on the other hand, are married in MBD marriages with local Tamang. These marriages subject Tamang males to the direct and daily status claims and associated labor obligations owed to their Ghale affines. Ghale marriages with Sertung villagers, a neighboring village far enough away that individuals are not exposed to daily reminders of status, are structurally similar to those with Kimtang. Thus, most of the Ghale women involved in MBD marriages with Sertung men are married into a Tamang clan with high prestige and power in local politics in that village. These Sertung men, by taking Ghale wives, appear to be operating in the same way as the Timling men with Kimtang wives. The general thrust of marriages made locally is to create an enduring status relationship that places Ghale in ascendance. When that is not possible, immediate balance (as in MBD-FZD marriages) or new relationships with no reflection on enduring patriline relations are attempted.

Figure 3, on the other hand, presents a contrasting pattern involving marriages within a relatively poor Tamang patriline entirely unrepresented by memorial mane for any ancestors. Here, many of the lineage males are involved in MBD marriages, predominantly with members of Ghale lineages within Timling itself. The three brothers who have taken MBD's from outside the village also resided uxorilocally after marriage. Unlike the Ghale, all MBD marriages for these men involve a close association with their ashyang-shyangbo and no protection from their labor demands. Households in this lineage typically own land at slightly lower than average amounts for Timling; a consequence of this has been some movement of lineage members to Timling's daughter settlements, formed when forest clearings and the temporary cattle shelters erected in them were converted into permanent settlements (Fricke 1986). Lack of land has also placed these lineage members in the position of willingness to accept MBD as wives in spite of the prestige disadvantages. Their material pay-off in exchange for the labor they provide their affines is potential access to land. The two figures suggest that patrilines have specific histories of marriage links that differ with respect to status claims within them. General contrasts between these two lineage marriage histories for generations IV and $V$ show striking differences consistent with patriline status claims. Fifty-nine per cent of the Tamang men in these two generations have entered into relationships placing them in a continuing one-way obligation flow compared to only 17 per cent of Ghale patriline men. At the same time, the Ghale patriline was able to give 45 per cent of its daughters and sisters in MBD marriages compared to just 8 per cent in the Tamang lineage. Moreover, proximity with affines as an important part of status claims has also been differently manipulated in the two lineages. Only 50 per cent of the Ghale men have wives from Timling compared to 76 per cent of the Tamang men. On the basis of these two dimensions alone we can see evidence of the manipulation of marriage characteristics to ratify status claims. 
ELEMENTARY STRUCTURES IN THE NEPAL HIMALAYA

Figure 2: History of Marriage Strategies in Wealthy Ghale Lineage

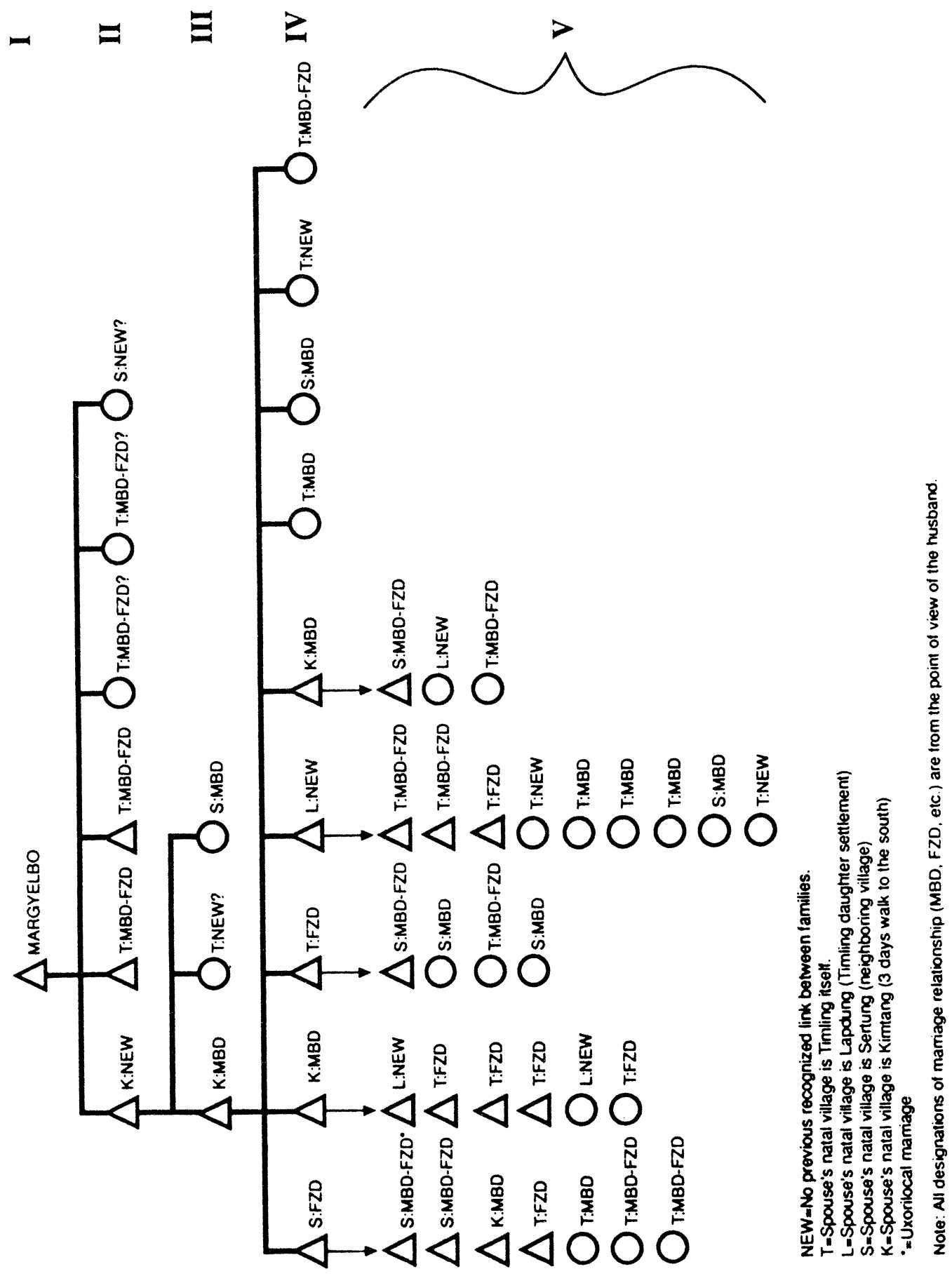


Figure 3: History of Marriage Strategies in Poor Tamang (Gomja Clan) Lineage

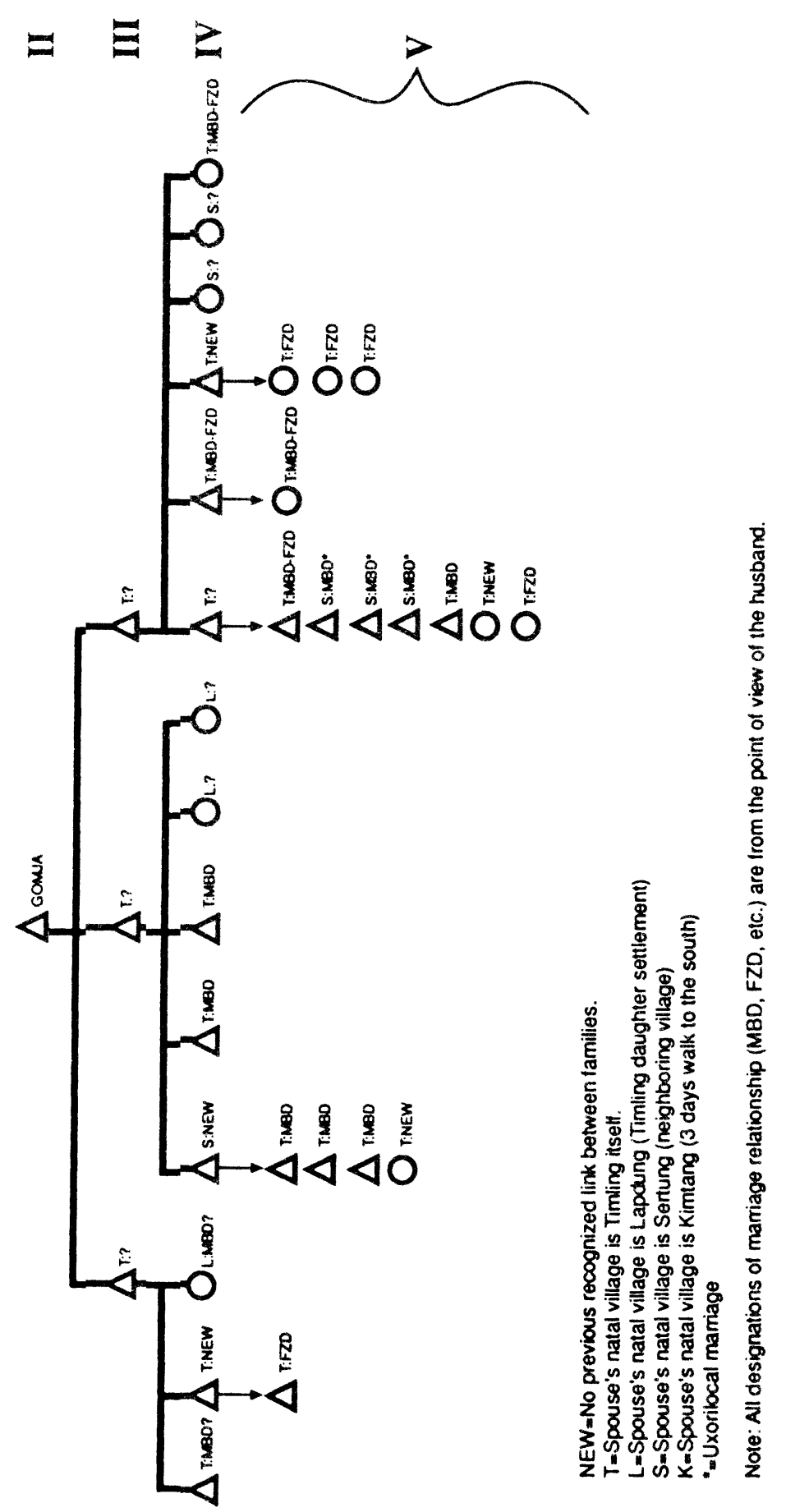


It is possible, of course, that the patterns of marriage in two nonrandomly chosen patrilines will not reflect the overall structuring of Timling marriages. A simple comparison of relatively wealthy and poor patrilines, moreover, might lead us to attribute different strategies to economic factors alone. Here I turn to a look at relationships based on the reports for the first marriages of women in the village born before 1956. Marriages among the 112 women $^{7}$ in these older cohorts more clearly reflect the stable pattern before increasing involvement in Nepal's wider wage labor economy. The look at marriage practice in two patrilines suggests that clan status, proximity of affines, and a woman's birth order may be important to the alliance structure of marriage. At the same time, the Tamang patriline history and the practice of providing land to poor sons-in-law may be related to the willingness of those men to enter into marriages that imply lower status.

Table 1 displays the distribution of first marriages for women along the dimension of implied hierarchy. A look at the relationships created by these first marriages shows that a high percentage (42 per cent) of them result in continuing reciprocal links implied by FZD or FZD-MBD marriage. This is especially true for the Tamang clans within which over half of these women's first marriages reproduce or create enduring exchange relations. Where a woman's senior kin are most heavily involved in the choice of her first spouse, the marriage is most likely to ratify these exchanges. Interestingly, when a woman confers more closely with her seniors regarding the marriage, the marriage is most likely to continue hierarchical relations between patrilines. The relation between affinal distance and these hierarchical marriages suggests a reason for this. Women who leave their natal villages to marry into Timling clans are more likely to enter into MBD marriages. Given the ability of women to refuse to accept the marriages arranged for them (Fricke 1986:136; Holmberg 1989:77), these sensitive marriages are more likely to involve discussion between daughters and their senior kin so that divorce and the consequent disruptions in social relations can be avoided.

The birth order of a daughter has an apparent relationship with marriage form, although not in the direction that one would expect were Timling people acting in simple adherence to the principle of reciprocity. Daughters who are also first borns are far less likely to be involved in the exchange marriages consistent with this principle. Later born daughters on the other hand appear to be more likely to enter into such reciprocal marriages.

Finally, the relationship between MBD marriages and the relative land of a husband's and wife's family is consistent with a picture in which men are willing to enter into relationships implying lesser status, in part, because some advantages can come from alliance with wealthier families. We have already seen one of these advantages to include the use of fields for one's own support.

With the exception of relative family land, the relationship between all of these characteristics of women and their families and the propensity to enter into reciprocal unions is statistically significant. When the relationship between MBD marriage and the relative land of families is looked at, however, the significance level is .068 . This suggests that the possibility of 
obtaining usufruct is a consideration in the willingness to accept subordinate statuses in MBD marriages.

Table 1

Marriage Structure and Its Relationship to Wife's and Family

Characteristics in Timling First Marriages

\begin{tabular}{|c|c|c|c|c|c|c|}
\hline & (Percent & $\begin{array}{l}\text { Marriage S } \\
\text { ge of Women }\end{array}$ & $\begin{array}{l}\text { ructure } \\
\text { in Each }\end{array}$ & tegory & & \\
\hline & $\begin{array}{c}\text { New Link } \\
\%\end{array}$ & $\begin{array}{c}\text { MBD Only } \\
\%\end{array}$ & $\begin{array}{c}F Z D \text { or } \\
\text { MBD-FZD } \\
\%\end{array}$ & $\begin{array}{c}\text { Total } \\
\%\end{array}$ & (N) & $\begin{array}{c}\text { Chi Square } \\
\text { sig. }^{2}\end{array}$ \\
\hline Total \% in Marriage & 29 & 30 & 42 & 101 & $(112)$ & \\
\hline 1. Wife's Clan & & & & & & .001 \\
\hline Tamang & 32 & 15 & 53 & 100 & $(60)$ & \\
\hline Ghale & 25 & 46 & 29 & 100 & $(52)$ & \\
\hline 2. Wife's Birth Position & & & & & & .047 \\
\hline First & 43 & 30 & 27 & 100 & (30) & \\
\hline Later & 23 & 29 & 48 & 100 & (82) & \\
\hline 3. Marital decision for Wife & & & & & & .000 \\
\hline Mostly Seniors & 15 & 25 & 60 & 100 & $(53)$ & \\
\hline Jointly & 13 & 60 & 27 & 100 & (15) & \\
\hline Mostly Wife & 50 & 25 & 25 & 100 & (44) & \\
\hline 4. Affinal Proximity & & & & & & .076 \\
\hline In Timling & 27 & 26 & 47 & 100 & (78) & \\
\hline Outside & 32 & 38 & 29 & 99 & (34) & \\
\hline 5. Relative Family Land & & & & & & .130 \\
\hline Equal/Husband More & 29 & 24 & 47 & 100 & (72) & \\
\hline Wife Family More & 28 & 40 & 33 & 101 & $(40)$ & \\
\hline
\end{tabular}

1These categories reflect recognized relationships with known genealogical links; at the same time, they are wider categories than actual first cousins.

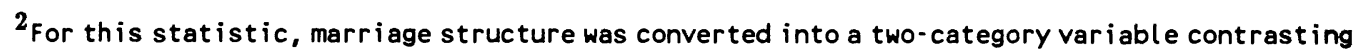
percentage of women in reciprocal ( $F Z D / F Z D-M B D$ ) marriages with the total percentage in both of the other categories (New Link and MBD) combined.

While the individual relationships between these characteristics of woman and their families and the forms of marriage they enter into provide a useful insight into marriage strategies it is still necessary to examine how they work 
as a system. Table 2 shows the results of multiple classification analyses performed to discover whether these relationships hold when all of these characteristics are considered together. ${ }^{8}$ Each of the characteristics of women and their families looked at in Table 1 has been related to the probability of entering into marriages that recreate reciprocal links. Here we find that reciprocal relationships implied by marriage are significantly related

Table 2

Multiple Classification of Proportion of Women in Reciprocal Marriage

(FZD/MBD-FZD) by Background Characteristics

\begin{tabular}{lccc}
\hline \hline & & Unadjusted \\
Characterististic & $(N)$ & Mean & Adjusted \\
Mean
\end{tabular}


to all but a woman's birth position when each characteristic is considered net of the others. This tells us that, while looking at birth position may be significant by itself, its effects are likely realized through other characteristics of the marriage such as how the marital decision is made. All of the other characteristics of women and their marriages included here are related to the likelihood that a marriage will recreate reciprocal links between patrilines. Tamang, clans are far more likely to be involved in such links. Marriages in which women's marriage choice are largely made by others are more likely to result in reciprocal ties. Reciprocal ties are more likely for marriages in which both families are from within the village itself. Finally, those first marriages in which a woman's family has more land than a husbands's family are less likely to be reciprocal.

\section{DISCUSSION AND CONCLUSIONS}

This descriptive exploration of Timling marriages has several implications for our understanding of marriage behavior in societies organized by kinship. Most generally, the variations in marriage form found among both Ghale and Tamang indicate that a search for positive marriage "rules" by themselves will not illuminate the practice of marriage in village society. The flexibility and strategic behavior we see in Timling are clearly parts of the system of marriage and politics itself.

If adherence to norms were the motivation for exchange, we would expect a woman's birth order to relate to marriage form. While birth position taken by itself is related, albeit in a manner unexpected by the need to fulfill obligations of reciprocity, its affects disappear when considered with other elements of the marriage process.

Other arguments for marriage outcomes focus on economic advantage and this is found to be an important part of the process for Timling. Thus relative land holdings of families entering into relationships through marriage are related to the structure of relationships implied by marriage form. Where relative holdings are equal or where a husband's family has more land than a wife's marriages are more likely to ratify prior reciprocal relations. Where a wife's family holds more land, Timling men are more likely to accept the lower status of forming either an entirely new subordinate relation or continuing an already existing one in MBD marriage. The evidence of observed patterns suggests that they do so in hopes of acquiring usufruct over excess affinal land.

But this economic rationale for particular outcomes is not the whole story since clan status--whether Ghale or Tamang--is powerfully related to the probability of entering into particular kinds of relationship in marriage. Because this relationship holds net of the other effects, our understanding of history and context in Timling becomes an important part of the interpretation of this relationship. That is, in spite of the "officializing" discourse in which both Ghale and Tamang argue for FZD and FZD-MBD exchanges, there is something about membership in these two groups that has an impact on marriage outcomes and the political relations implied by them. These features of group membership are apart from economic differences (relative land holdings), senior generation involvement in marital decisions (choice of spouse), and political relations measured by the ability of affines 
to demand services (affinal proximity). In light of Timling's history and the conflicting models of hierarchy and reciprocity that can be appealed to for validating behavior, there is some support here for the need to consider other avenues by which relations are unconsciously replicated in marriage (Bourdieu 1976:120). In any event, it is clear that the meaning of marriage strategies in Timling requires attention to the dual systems of prestige that turn on social difference in addition to other, more easily measured, parts of the process.

Finally, the processes by which statuses are created and renewed in Timling may apply more generally among Himalayan societies. The literature include (1) frequent reports of indigenous, of ten idiosyncratic, systems of hierarchy and marriage in a range of nominally egalitarian Tibeto-Burmese groups in the Himalaya (Levine 1988: Pignéde 1962; Messerschmidt 1976; Allen 1978; Aziz 1978); (2) the evidence for closely related hierarchical structures in the entire upper Ankhu Valley and nearby regions (Toffin 1976; 1986; Clarke 1980); and (3) the existence of single Ghale clans in a number of villages, each faced with the same problem of inherited rank and clan exogamy within overarching reciprocal marriage environments. Even where high rank is claimed by a multi-clan endogamous tier within a wider society, ethnographers report marriages across these lines and suggest indigenous strategies for raising statuses (Macfarlane 1976:17-19; Levine 1988).

We have seen for Timling that wives are required for men to begin to make status claims at any level. In fact, wives are required for any man to even begin recognized existence as the head of a domestic group. We have also seen that prestige claims and status exist on a continuum from minimal fulfillment of the requirements of sociality to more general levels of giving, but all phrased in terms of a central logic involving reciprocity. People in Timling have a choice, however hemmed in by claims to inherited status and the history of relationships in their pasts, about whether to pursue the forms of prestige that lead to political power in the village arena or to settle for the more domestic forms of power that come in various ways to every man. Each marriage constitutes a moment in the pursuit of whatever statuses are being claimed, either as a strategy in the renewal of prior claims or as a starting point for new ones.

The possibilities for these claims are circumscribed by culturally given avenues to prestige--in this case, avenues defined by the network of those in reciprocal imbalance. Any person, subject to the constraints of history, may seek to enlarge these networks by beginning to manipulate the structure of affinal obligations through his own marriage and the marriages of his children.

\section{NOTES}

1. Support for data collection in 1987-88 and analysis was provided by NICHD grant number 1 RO1 HD22543 and NSF award number SES-8607288. I acknowledge permission from His Majesty's Government of Nepal to conduct field research. Many thanks to Tshelthapa Damrong, Sirman Ghale, Lama Mingmar Ghale, Chibe Ghale, Tschering Lama, and Meena Tamang for help in the field. An earlier version of this paper was presented at the 1989 AAA meetings on the panel "Marriage, Politics, and the Organization of Inequality: From the Himalaya to Central Asia." Thanks to Laura Ahearn, Bill Axinn, Judy Baughn, Jim Hagen, Dan 
Hill, David Holmberg, Ray Kelly, Nancy Levine, Sherry Ortner, Gloria Raheja, Arland Thornton, and Linda Young-Demarco for comments and technical help.

2. The people of Timling speak the western Tamang dialect described in Taylor (1973) and Taylor et al. (1972). Even within this larger dialect area, however, variants are spoken from village to village. Mixes of Nepali loanwords also vary across villages. In this paper, Tamang words are designated "Tm" and Nepali "Np".

3. The butchering and distribution process is itself a reflection on the ideology of "oneness" in Timling. Widespread in Tamang and, more generally, Tibeto-Burman areas are myths that tie particular cuts of meat to different status groups, either within a single society or in crosscaste rankings (Macdonald 1979; cf. Holmberg 1989:34-37). In Timling, any animal is butchered for distribution in such a way that each share, regardless of its relative size, includes a proportional bit from every part of the animal. This is accomplished by successive halvings of the animal and each organ until the distribution is complete. In the context of these mythic themes, the solidarity conveyed is unmistakable.

4. These mane are the Timling (and, more generally, Tamang) versions of Tibetan chorten, or stupa. In addition to those built as memorials, they are also built for particular deities ( $\mathrm{Tm}$.

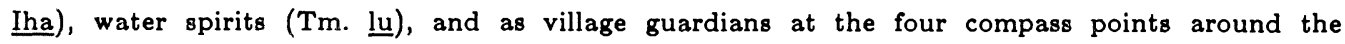
village.

5. In the local system, Ghale rank highest and are associated with royalty, followed by the four Tamang clans. Damrong are known as the ministerial clan. Gomja and Mepa, two clans said to have descended from different co-wives of a common male ancestor, are associated with religious specialists in Timling. Tellingly, Mepa are descended from the first wife and are classed as Buddhist religious specialists ( $\mathrm{Tm}$. lama). Gomja, descended through the second wife, are classed as shamans ( $\mathrm{Tm}$. bombo). Finally Mamba rank as commoners in this system. It was into this last clan that slaves (Tm. gyappa) manumitted by the Nepal state in 1926 were incorporated.

6. Timling Ghale claim to be an entirely separate group from the clan known as Ghale among the Gurung to the west. Although the state referred to western Ghale as Gurung in the legal code of 1854 (Höfer 1979), a legal document dated 1873 found in Timling's Gompo clearly recognizes the Ghale of Timling as a distinct and non-Gurung entity. Nevertheless, Timling Ghale and Gurung Ghale status claims are similar and there is likely an historical relationship (cf. Mumford 1989).

7. In Timling at the time of 1987-88 fieldwork, 114 women were born before 1956. I include only 112 women for which I have complete information on first marriages in the following analyses.

8. The "unadjusted" mean shows the proportion of women in reciprocal unions for each characteristic considered by itself, as in Table 1. The "adjusted" column in this table presents the relationship between each characteristic and the likelihood that a marriage will constitute a reciprocal relationship net of the effects of the other characteristics. The tests of statistical significance tell us the probability that this relationship is random. Readers desiring a very readable account of multiple classification analysis should consult Andrews et al. (1973).

\section{BIBLIOGRAPHY}

Acharya, M., and L. Bennett. 1981. The Rural Women of Nepal: An Aggregate Analysis and Summary of 8 Village Studies. Kathmandu.

Allen, N. J. 1978. Quadripartition of Society in Early Tibetan Sources. Journal Asiatique 266:341-359. 
Andrews, F., J. Morgan, J. Sondquist, and L. Klem. 1973. Multiple Classification Analysis, Second Edition. Ann Arbor.

Aziz, B. 1978. Tibetan Frontier Families: Reflections of Three Generations from D'ing-ri. New Delhi.

Bourdieu, P. 1976. Marriage Strategies as Strategies of Social Reproduction. Family and Society: Selections from the Annales, ed. R. Forster and O. Ranum, pp. 117-146. Baltimore. 1977. Outline of a Theory of Practice. Cambridge.

Bradburd, D. 1984. The Rules and the Game: The Practice of Marriage among the Komachi. American Ethnologist 11:738-753.

Clarke, G. 1980. Lama and Tamang in Yolmo. Tibetan Studies in Honour of Hugh Richardson, ed. M. Aris and A. S. S. Kyi, pp. 79-88. Warminster, England.

Collier, J. F. 1988. Marriage and Inequality in Classless Societies. Stanford.

Fricke, T. E. 1986. Himalayan Households: Tamang Demography and Domestic Processes. Ann Arbor.

Fürer-Haimendorf, C. von 1956. Ethnographic notes on the Tamangs of Nepal. Eastern Anthropologist 9:166-177.

Hitchcock, J. T. 1980. A Mountain Village in Nepal. New York.

Höfer, A. 1969. Preliminary Report on a Field Research in a Western Tamang Group. Bulletin of the International Committee for Urgent Anthropological and Ethnological Research 11:17-31.

1979. The Caste Hierarchy and the State in Nepal: A Study of the Muluki Ain of 1854. Innsbruck.

Holmberg, D. H. 1989. Order in Paradox: Myth, Ritual, and Exchange among Nepal's Tamang. Ithaca.

Keesing, R. M. 1967. Statistical Models and Decision Models of Social Structure: A Kwaio Case. Ethnology 6:1-16.

Leach, E. R. 1961. The Structural Implications of Matrilateral Cross-cousin Marriage. Rethinking Anthropology, pp. 54-104. London.

1977. Political Systems of Highland Burma: A Study of Kachin Social Structure. London.

Lévi-Strauss, C. 1969. The Elementary Structures of Kinship. Boston.

Levine, N. 1981. The Theory of Rü Kinship: Descent and Status in a Tibetan Society. Asian Highland Societies in Anthropological Perspective, ed. C. von Fürer-Haimendorf, pp. 52-78. New Delhi.

1988. The Dynamics of Polyandry: Kinship, Domesticity, and Population on the Tibetan Border. Chicago.

Macdonald, A. W. 1980. Creative Dismemberment among the Tamang and Sherpas of Nepal. Tibetan Studies in Honour of Hugh Richardson, ed. M. Aris and A. S. S. Kyi, pp. 199-208. Warminster, England.

Macfarlane, A. 1976. Resources and Population: A Study of the Gurungs of Nepal. Cambridge.

March, K. S. 1979. The Intermediacy of Women: Female Gender Symbolism and the Social Position of Women among Tamangs and Sherpas of Highland Nepal. Ph.D. dissertation in Anthropology, Cornell University. 1984. Weaving, Writing, and Gender. Man (N.S.) 18:729-44. 1987. Hospitality, Women, and the Efficacy of Beer. Food and Foodways 1:351-387.

Messerschmidt, D. 1976. The Gurungs of Nepal: Conflict and Change in a Village Society. Warminster, England. 
Molnar, A. 1978. Marital Patterns and Women's Economic Independence: A Study of Kham Magar Women. Contributions to Nepalese Studies 6:15-29.

Mumford, S. R. 1989. Himalayan Dialogue: Tibetan Lamas and Gurung Shamans in Nepal. Madison.

Murdock, G. P. 1949. Social Structure. New York.

Ortner, S. B. 1978. Sherpas through their Rituals. Cambridge. 1984. Theory in Anthropology Since the Sixties. Comparative Studies in Society and History 26:126-66. 1989. High Religion: A Cultural and Political History of Sherpa Buddhism. Princeton.

Pignéde, B. 1962. Clan Organization and Hierarchy among the Gurungs. Contributions to Indian Sociology 6:102-119.

Stiller, L. F. 1973. The Rise of the House of Gorkha: A Study in the Unification of Nepal, 1768-1816. Kathmandu.

Taylor, D. 1973. Clause Patterns in Tamang. Clause, Sentence and Discourse Patterns in Selected Languages of Nepal, pp. 81-174. Kathmandu.

Taylor, D., F. Everitt, and K. B. Tamang. 1972. A Vocabulary of the Tamang Language. Kathmandu.

Toffin, G. 1976. The People of the Upper Ankhu Khola Valley. Contributions to Nepalese Studies 3:34-46.

1986. Unités de parenté, système d'alliance et de prestations chez les Tamang de l'ouest (Népal). Anthropos 81:21-46.

Zurick, D. N. 1989. Historical Links between Settlement, Ecology, and Politics in the Mountains of West Nepal. Human Ecology 17:229-255. 
http://www.jstor.org

\section{LINKED CITATIONS}

- Page 1 of 2 -

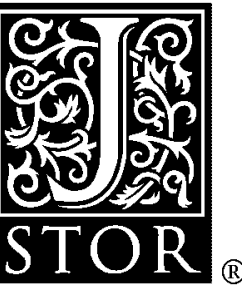

You have printed the following article:

Elementary Structures in the Nepal Himalaya: Reciprocity and the Politics of Hierarchy in Ghale-Tamang Marriage

Thomas E. Fricke

Ethnology, Vol. 29, No. 2. (Apr., 1990), pp. 135-158.

Stable URL:

http://links.jstor.org/sici?sici=0014-1828\%28199004\%2929\%3A2\%3C135\%3AESITNH\%3E2.0.CO\%3B2-3

This article references the following linked citations. If you are trying to access articles from an off-campus location, you may be required to first logon via your library web site to access JSTOR. Please visit your library's website or contact a librarian to learn about options for remote access to JSTOR.

\section{Bibliography}

The Rules and the Game: The Practice of Marriage among the Komachi

Daniel Bradburd

American Ethnologist, Vol. 11, No. 4, Social Structure and Social Relations. (Nov., 1984), pp. 738-753.

Stable URL:

http://links.jstor.org/sici?sici=0094-0496\%28198411\%2911\%3A4\%3C738\%3ATRATGT\%3E2.0.CO\%3B2-L

\section{Statistical Models and Decision Models of Social Structure: A Kwaio Case}

Roger M. Keesing

Ethnology, Vol. 6, No. 1. (Jan., 1967), pp. 1-16.

Stable URL:

http://links.jstor.org/sici?sici=0014-1828\%28196701\%296\%3A1\%3C1\%3ASMADMO\%3E2.0.CO\%3B2-N

\section{Weaving, Writing and Gender}

Kathryn S. March

Man, New Series, Vol. 18, No. 4. (Dec., 1983), pp. 729-744.

Stable URL:

http://links.jstor.org/sici?sici=0025-1496\%28198312\%292\%3A18\%3A4\%3C729\%3AWWAG\%3E2.0.CO\%3B2-P 
http://www.jstor.org

\section{LINKED CITATIONS \\ - Page 2 of 2 -}

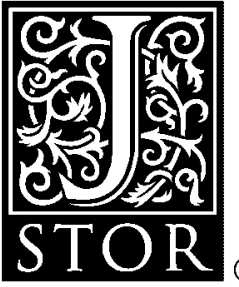

Theory in Anthropology since the Sixties

Sherry B. Ortner

Comparative Studies in Society and History, Vol. 26, No. 1. (Jan., 1984), pp. 126-166.

Stable URL:

http://links.jstor.org/sici?sici=0010-4175\%28198401\%2926\%3A1\%3C126\%3ATIASTS\%3E2.0.CO\%3B2-T 